\title{
Large-scale Identification of Expressed Sequence Tags (ESTs) from Nicotiana tabacum by Normalized cDNA Library Sequencing*
}

\author{
by \\ Sandra Pérez Alvarez ${ }^{1}$, Daniel Cabezas Montero ${ }^{1}$ and Hai-Tao Dong ${ }^{2}$ \\ ${ }^{1}$ Agrarian University of Havana, Havana, Cuba \\ ${ }^{2}$ Bioinformatics and Gene Network Research Group, Zhejiang University, Hangzhou, 310029, China
}

\section{SUMMARY}

An expressed sequence tags (EST) resource for tobacco plants (Nicotiana tabacum) was established using highthroughput sequencing of randomly selected clones from one cDNA library representing a range of plant organs (leaf, stem, root and root base). Over 5000 ESTs were generated from the 3' ends of 8000 clones, analyzed by BLAST searches and categorized functionally. All annotated ESTs were classified into 18 functional categories, unique transcripts involved in energy were the largest group accounting for 831 (32.32\%) of the annotated ESTs. After excluding 2450 non-significant tentative unique transcripts (TUTs), 100 unique sequences (1.67\% of total TUTs) were identified from the $N$. tabacum database. In the array result two genes strongly related to the tobacco mosaic virus (TMV) were obtained, one basic form of pathogenesis-related protein 1 precursor (TBT012G08) and ubiquitin (TBT087G01). Both of them were found in the variety Hongda, some other important genes were classified into two groups, one of these implicated in plant development like those genes related to a photosynthetic process (chlorophyll a-b binding protein, photosystem I, ferredoxin I and III, ATP synthase) and a further group including genes related to plant stress response (ubiquitin, ubiquitin-like protein SMT3, glycine-rich RNA binding protein, histones and methallothionein). The interesting finding in this study is that two of these genes have never been reported before in $N$. tabacum (ubiquitin-like protein SMT3 and methallothionein). The array results were confirmed using quantitative PCR. [Beitr. Tabkaforsch. Int. 22 (2006) 114-124]

\section{ZUSAMMENFASSUNG}

Eine Quelle für „Expressed Sequence Tags” (EST), also eine exprimierte RNA-Sammlung für Tabakpflanzen (Nicotiana tabacum), wurde in großem Maßstab durch die Sequenzierung von zufällig ausgewählten Klonen einer cDNA-Bibliothek etabliert, die eine Reihe von Pflanzenorganen (Blatt, Stiel, Wurzel und Wurzelbasis) präsentiert. Über 5000 ESTs von 8000 Klonen wurden vom 3'-Ende generiert, durch das Computerprogramm BLAST analysiert und funktional kategorisiert. Alle beschriebenen ESTs wurden in 18 funktionale Kategorien klassifiziert. Einzelne Transkripte, die dem Energiehaushalt zugeordnet werden konnten, waren mit 831 (32,32\%) die größte Gruppe von allen beschriebenen Sequenzen. Nach dem Ausschluss von 2450 nicht signifikanten „Tentative Unique Transcripts” (TUTs) wurden 100 einzelne Sequenzen (1,67\% von allen TUTs) in der Datenbank von N. tabacum identifiziert. In der Versuchsreihe wurden zwei Gene gefunden, die eine hohe Verwandtschaft mit dem Tabakmosaikvirus (TMV) aufweisen, die basische Form der Pathogenesis-Related Protein 1-Vorstufe (TBT012G08) und Ubiquitin (TBT087G01). Beide Gene wurden in der Varietät Hongda gefunden. Andere wichtige Gene wurden zwei Gruppen zugeordnet, die eine Gruppe bezog sich auf die Pflanzenentwicklung, wie z.B. Gene für den Photosyntheseprozess (Chlorophyll a-b bindende Proteine, Photosystem I, Ferredoxin I und III, ATP-Synthase), die andere Gruppe enthielt die Gene für Stressreaktionen (Ubiquitin, das Ubiquitinähnliche Protein SMT3, Glycin-reiche RNA-bindende Proteine, Histone, und Metallothionein). Das Interessante an dem Ergebnis dieser Studie ist, dass zwei dieser Gene noch nie vorher in N. tabacum beschrieben wurden (das 
Ubiquitin-ähnliche Protein SMT3 und Metallothionein). Die Array-Ergebnisse wurden durch Quantitative PCR bestätigt. [Beitr. Tabakforsch. Int. 22 (2006) 114-124]

\section{RESUME}

Une collection d'ESTs (Expressed Sequence Tags) de tabac (Nicotiana tabacum) a été constituée en utilisant le séquençage à haut débit de clones choisis de façon arbitraire à partir d'une librairie d'ADNc représentant divers organes de plantes (feuille, tige, racine, et base de racine). Plus de 5000 ESTs ont été générés à partir de l'extrémité 3' de 8000 clones, analysés par une recherche de type BLAST et caractérisés fonctionnellement. Toutes les annotations d'ESTs ont été classifiées en 18 catégories fonctionnelles. Les transcrits uniques impliqués dans l'énergie représentent le groupe le plus important, avec 831 (32.32\%) annotations ESTs. Après l'exclusion de 2450 séquences uniques (TUTs) non significatives, 100 séquences uniques ( $1.67 \%$ des TUTs totales) ont été identifiées à partir de la base de données tabac. Dans cet ensemble de résultats, deux gènes fortement liés au virus de la mosaïque du tabac (VMT) ont été obtenus, une forme basique d'un précurseur de la protéine PR-1 (pathogenesis-related protein) (TBT012G08) et l'ubiquitine (TBT087G01), les deux ont été trouvés dans la variété Hongda. D'autres gènes importants ont été rassemblés en deux groupes de gènes, l'un impliqué dans le développement de la plante comme les gènes liés au processus de la photosynthèse (chlorophyll $\mathrm{a}-\mathrm{b}$ binding protein, photosystem I, ferredoxin I and III, ATP synthase) et l'autre groupe incluant des gènes liés aux réponses au stress (ubiquitin, ubiquitin-like protein SMT3, glycine-rich RNA binding protein, histones and methallothionein). La découverte intéressante dans cette étude est que deux de ces gènes n'ont jamais été cités auparavant dans $N$. tabacum (une ubiquitin-like protein SMT3 et la methallothionéine). L'ensemble de ces résultats a été confirmés par PCR quantitative [Beitr. Tabakforsch. Int. 22 (2006) 114-124]

\section{INTRODUCTION}

Large-scale, partial sequencing of randomly selected cDNA clones, to generate expressed sequence tags (ESTs) has become an indispensable part of genomic research. Generating ESTs is a rapid method of sampling an organisms transcriptome and is therefore complementary to whole genome-sequencing programs $(1,2)$.

Although cultivated tobacco is of great economic significance, relatively little information exists on its genome structure and organization. Tobacco is studied as a plant model for gross genome structure and function because of its well-characterized amphidiploids genetic background (15). Characterization of different ESTs provide information of the agronomic importance of the tobacco genome. Because an EST is usually unique to a particular cDNA, and because cDNAs correspond to a particular gene in the genome (1), ESTs have been used in this study to help identify unknown genes, especially those related to the tobacco mosaic virus (TMV), and to map their position in the genome in tobacco plants.
In this research, one cDNA library population that included leaves, stem, roots and root bases of four varieties of tobacco plants "Nicotiana tabacum" was generated to develop a database of 5927 ESTs. The expression profiles of these genes were compared and analyzed to discuss their possible roles in disease resistance and crop quality. The enrichment provided by cDNA cloning in combination with the efficiency of cDNA arrays was an effective approach in this study to start identifying developmentally regulated genes in tobacco. This experiment was carried out at the bioinformatics and gene network research group in the Biotechnology Institute of Zhejiang University in the period of 2001-2005, People's Republic of China.

\section{MATERIALS AND METHODS}

\section{Plant material}

Four varieties of tobacco from Yunnan Province (Hongda, NC82, YH05 and YUN201) were grown in soil until the plants were about $10 \mathrm{~cm}$ high. Leaves, stems, roots and root bases were used for library construction.

\section{cDNA library construction}

A sample of $5 \mathrm{~g}$ of tobacco leaves, stems, roots and roots base were powdered in a mortar with liquid $\mathrm{N}_{2}$ using TRIZOL® reagent according to the manufacturer's protocol (GIBCO-BRL, Grand Island, N.Y; Life Technologies) and used for total RNA extraction. Isolation of Poly A + mRNA from total RNA was done according to the manufacturer's protocol (QIAGEN's Oligotex mRNA Spin-Column). Double-stranded cDNAs were synthesized with the Universal RiboClone® cDNA Synthesis System (Promega). A cDNA longer than 400 bp was directionally ligated into pBlue script SK (+) vector that had been digested with NotI And SalI. The recombinant plasmid was transformed into E. coli $\mathrm{DH} 5 \alpha$ using a Gene Pulser $\mathrm{X}$ cell $^{\mathrm{TM}}$ Electrophoretion System (Bio-Rad).

\section{Template preparation}

cDNA library clones were plated on $1.5 \%$ agar solid LB medium ( $\mathrm{pH} 7.0$ ) with $100 \mu \mathrm{g} / \mathrm{mL}$ ampicillin and incubated at $37{ }^{\circ} \mathrm{C}$ overnight. Randomly selected single white bacterial colonies were picked with toothpicks and were placed in each well of a 96 Square-Well block with 2YT at pH 7.0, containing the appropriate selective agent. Cultures were allowed to grow overnight by shaking the plates at $200 \mathrm{rpm}$ at $37{ }^{\circ} \mathrm{C}$ and then stored at $70{ }^{\circ} \mathrm{C}$. Plasmid DNA was prepared by a modified alkaline lysis protocol using a plasmid DNA purification kit (Millipore). The results of the isolation were analyzed by agarose gel electrophoresis, and then sequenced.

\section{Sequencing and analysis}

EST sequences were subjected to quality control screening as follows. Base calling and quality control were performed by using phred (12). Sequence reactions were run and analyzed from the 3' end of each cDNA on a MegaBACETM 1000 
automated sequencer (MD) using the DYEnamic ET Dye Terminator Cycle Sequencing Kit (Amersham Pharmacia Biotech). The primer used was a standard M13 forward primer: 5'-CCCAGTCACGACGTTGTAAAACG-3' .

Raw data from the sequencer were processed manually and carefully with a view to acquiring high-quality ESTs. First, sequences were exported after low-quality sequences were removed with reference to original trace data, using Chromas 1.45 software. Second, ESTs shorter than $160 \mathrm{bps}$ and containing more than $3 \%$ ambiguous bases were considered not useful for further data analysis and excluded. Finally, all ESTs with at least 16 of the final 20 bases as adenine were assumed to contain poly $(\mathrm{A}+)$ tails, and were selected for further analysis after vector trimming, for 3' UTR can represent unique gene expression. The ESTs without poly $(\mathrm{A}+)$ tails were organized as a second dataset but they were not included in any further analysis.

\section{Normalization}

The problem of sequence redundancy has been outlined by SOARES and colleagues (29). Normalization was done by introducing a hybridization step between the ESTs. A short reassociation time ensures that only the most abundant sequences are removed by this process (29).

\section{ESTs data analysis}

Classification of clones was based on their similarity to Genebank database entries. BLASTX and BLASTN programs (4) were used to search for similarity to proteins and nucleic acids, respectively. Default parameters were used for both programs. EST sequences from both pools also were compared with the non-redundant and the dbEST databases. In general, similarities with probabilities $<10^{-4}$ were considered significant. Gene sequences from a cDNA population has been deposited in the Genebank EST database (http://www.estarray.org/san/xest/index.asp?sp=tbt).

\section{EST clustering}

Every EST sequence subjected to BLAST searching was used to construct a BLAST database. The EST sequences were then considered as BLASTN queries against this database. ESTs that produced an alignment with another EST with an overlap of 100 bases with $95 \%$ identity were linked with that EST to produce a cluster.

\section{Preparation of cDNA-array}

The unique cDNA clones were randomly collected and amplified by means of PCR in a 96-well format on the basis of primer pairs specific for the vector ends, $100 \mu \mathrm{L}$ of PCR mixture containing $10 \mu \mathrm{L}$ of $10 \times$ PCR buffer, $7 \mu \mathrm{L}$ of 25 $\mathrm{mM} \mathrm{MgCl} 2,1 \mu \mathrm{L}$ of $20 \mathrm{mM}$ dNTP, $1 \mu \mathrm{L}$ of $100 \mathrm{ng} / \mu \mathrm{L}$ M13 forward and M13 reverse respectively (M13 forward, 5'cccagtcacgacgttgtaaaacg-3', and M13 reverse, 5'agcggataacaatttcacacagg-3'), 3 units of Tac DNA polymerase (Promega) and approximately $10 \mathrm{ng}$ of plasmid template. The reactions were run on a multi-block system (MBS) thermocycler (ThermoHybaid, Ashford, UK) using an amplification program of 5 min denaturation at $94{ }^{\circ} \mathrm{C}$, then followed by 36 cycles of $30 \mathrm{~s}$ at $94{ }^{\circ} \mathrm{C}, 60 \mathrm{~s}$ at $58{ }^{\circ} \mathrm{C}$, and $90 \mathrm{~s}$ at $72{ }^{\circ} \mathrm{C}$, and terminated by a $10 \mathrm{~min}$ extension at $72{ }^{\circ} \mathrm{C}$. The PCR products were precipitated by adding $100 \mu \mathrm{L}$ of isopropylalcohol and $10 \mu \mathrm{L}$ of sodium acetate (3 M, pH 5.2) and centrifuging at $3500 \times \mathrm{g}$ at $4{ }^{\circ} \mathrm{C}$ for $35 \mathrm{~min}$. The DNA precipitate was washed with $70 \%(\mathrm{w} / \mathrm{v})$ ethanol and centrifuged at $3500 \times \mathrm{g}$ for $20 \mathrm{~min}$ again. When dried, the precipitate was suspended in $15 \mu \mathrm{L}$ of denatured solution (0.4 M NaOH and $10 \mathrm{mM}$ EDTA), waiting for printing. An array was produced by using GeneTAC TM G3 arrayer (Genomic Solution), the spots (approximately $150 \mu \mathrm{m}$ in diameter) were printed on the filter (Hybrid $\mathrm{N}+$ ) arranged in a $24 \times 16$ large array. Duplicate spots of each cDNA were arrayed adjacently to enable the reproducibility of experiments to be verified.

\section{Preparation of labeled cDNA}

To generate probes, PCR products were labeled with radioactive $\mathrm{dCT}^{33} \mathrm{P}$ using random primed labeling. Each reaction $(50 \mu \mathrm{L})$ consisted of $50 \mathrm{ng}$ of total RNA, $5 \mu \mathrm{g}$ of oligo(dT) 16 primers, $300 \mathrm{pmol}$ of random hexamer, $30 \mathrm{mM}$ each of dATP, dTTP, dGTP and $5 \mu \mathrm{L}$ of $\alpha{ }^{3}{ }^{33} \mathrm{P}-\mathrm{dCTP}(10 \mathrm{mCi} / \mathrm{ml}$, Amersham Biosciences), $10 \mu \mathrm{L}$ of $5 \times$ reaction buffer provided with reverse transcriptase (Life Technologies), $0.5 \mathrm{mM}$ DTT and 400 unit superscript II reverse transcriptase (Life Technologies). Total RNA and primers were heated to $70{ }^{\circ} \mathrm{C}$ for $5 \mathrm{~min}$ and quickly cooled on ice before the remain reaction continue for $1 \mathrm{~h}$ at $37^{\circ} \mathrm{C}$ pre-incubation followed by $2 \mathrm{~h}$ at $42{ }^{\circ} \mathrm{C}$, and then $50 \mu \mathrm{L}$ TEN buffer $(40 \mathrm{mM}$ Tris- $\mathrm{Cl} \mathrm{pH}$ 7.5, $1 \mathrm{mM}$ EDTA pH 8.0, $150 \mathrm{mM} \mathrm{NaCl}$ ) were added. Each of the labeled cDNA products were purified using G-50 column (Amersham biosciences), the purified labeled cDNA products were incubated at $70{ }^{\circ} \mathrm{C}$ for $5 \mathrm{~min}$ and then cooled on ice before hybridization.

\section{Array hybridization and data analysis}

Hybridization was performed overnight at $60{ }^{\circ} \mathrm{C}$ in a hybridization oven. Washing was done at $60{ }^{\circ} \mathrm{C}$ in $2 \times \mathrm{SSC}$ and $0.1 \%$ SDS for $20 \mathrm{~min}$ and twice in $0.1 \times \mathrm{SSC}$ and $0.1 \%$ SDS for $20 \mathrm{~min}$. The signals of the array were absorbed by storage phosphor screen for 2 days, and the signal intensities were measured by scanning the storage phosphor screen with the Typhoon 9200 (Molecular Dynamics).

Spot finding and analysis of signal intensity were quantified based on ArrayVision 6.0 (Amersham Pharmacia Biotech) software. Normalization was performed after adjusting the total signal intensity of the image (global normalization). To ensure the results were reproducible, three individual hybridization experiments were performed for each probe, and pairwise linear comparisons were made for which the correlation coefficients $\left(R^{2}\right)$ were between 0.89 and 0.94 . Changes of expression of every gene between two different tissues was assessed using the $t$-test. We selected 0.01 as an appropriate confidence level, and when $t$ exceeded this threshold, the two populations were considered to be different.

\section{Quantitative PCR}

Quantitative PCR with gene-specific primers was used to confirm some of the results obtained with the cDNA 
Table 1. Analysis of $N$. tabacum ESTs

\begin{tabular}{lc}
\hline EST summary & Values \\
\hline Total ESTs & 5927 \\
Mean EST length (nt) & 351 \\
Number of TUTs & 3600 \\
Number of contigs & 521 \\
Redundancy(\%) ${ }^{a}$ & 48.1 \\
Number of singletons & 3079 \\
Cotigs sizes & \\
$2-5$ ESTs & 426 \\
$6-10$ ESTs & 46 \\
$11-15$ ESTs & 20 \\
$16-20$ & 11 \\
$21-30$ ESTs & 9 \\
$\geq 31$ ESTs & 9 \\
G + C content $(\%)$ & 43.6 \\
\hline
\end{tabular}

${ }^{a}$ Redundancy $=$ ESTs assembled in contigs/total ESTs.

array. Genes of interest were detected by using primers that had been optimized to generate a single amplicon of $\sim 80$ bp nucleotides. Reactions were performed in 96-well plates with optical sealing tape (Bio-Rad) and contained $25 \mu \mathrm{L}$ total volumes. Beta-actin primers (5' TTGTAACCAACTGGGACGATATGG-3' and 3'GATCTTGATCTTCATGGTGCTAGG 5') were used in parallel for each run. The PCR amplification was carried out with an initial step at $93{ }^{\circ} \mathrm{C}$ for 1 min followed by 50 cycles of $10 \mathrm{~s}$ at $93{ }^{\circ} \mathrm{C}, 20 \mathrm{~s}$ at $60{ }^{\circ} \mathrm{C}$ and $10 \mathrm{~s}$ at $72{ }^{\circ} \mathrm{C}$. The relative expression of the gene of interest was determined by calculating the ratio of the extrapolated concentration of that gene to the extrapolated concentration of $\beta$-actin.

\section{RESULTS}

\section{EST sequencing and assembly}

A total of 5927 sequences were generated from the 3' ends of clones selected from four varieties of Nicotiana tabacum normalized cDNA library with a mean insert size of $1.2 \mathrm{~kb}$. All ESTs with an average read length of 351 nucleotides following vector and low-quality sequence trimming (see Sequencing and analysis) were submitted to the NCBI database. The library results after further analysis are summarized in Table 1. From this dataset 521 contigs and 3079 singletons were formed after the assembly of the 5927 ESTs.

The results showed 3600 TUTs including 3079 singletons ( $85.53 \%$ in TUTs) and 521 contigs. The number of contigs with twenty or more ESTs presumably representing highly expressed genes were 18 (3.45\% in contigs, $0.50 \%$ in TUTs), and the remaining 503 contigs ( $96.54 \%$ in contigs, $13.97 \%$ in TUTs respectively) were used to represent genes expressed moderately. G + C content was $43.6 \%$ in all assembled EST sequences.

A redundancy of $48.1 \%$ was found in this set of sequences (Table 1). Most of the highly redundant sequences were housekeeping genes which in this study are genes involved in energy and metabolism (see Table 3 ). This category of
Table 2. BLASTX results of TUTs

\begin{tabular}{lcc}
\hline Sequence matches $^{\text {a }}$ & No. of TUTs & Percentage (\%) \\
\hline Significant matches & & \\
High & 696 & 19.33 \\
$\quad$ Moderate & 300 & 8.33 \\
$\quad$ Weak & 154 & 4.27 \\
Not significant matches & 2450 & 68.05 \\
All TUTs & 3600 & 100.00 \\
\hline
\end{tabular}

a The TUT sequence matches were divided into highly significant $\left(E \leq 10^{-20}\right)$, moderately significant $\left(10^{-20}<E \leq 10^{-10}\right)$, weakly significant $\left(10^{-10}<E \leq 10^{-5}\right)$ and not significant $\left(E>10^{-5}\right)$ classes according to the expected $(E)$ values of BLASTX hit sequences.

genes, along with those for protein synthesis, destination and storage are sampled more often by random sequencing of cDNA libraries, which reflects their general housekeeping role (26).

\section{Normalization}

About $50 \%$ of the ESTs from the normalized library were unique; such result is near to the expected result from normalization $(66.7 \%)$ (22). Therefore, the increase in diversity comes at the price of a sharp increase in the number of housekeeping genes in the library and this produces a high percent of redundancy.

\section{Functional annotation and classification}

Table 2 shows 3600 non-redundant sequences that were examined based on BLASTX searches of the GenBank database. There were 696 unique sequences $(19.33 \%$ of TUTs) which were identified as highly significant matches $\left(\mathrm{E} \leq 10^{-20}\right)$ to known gene sequences and was regarded as representative of known genes. There were 2450 TUTs (68.05\% of TUTs) which had no significant match in sequence similarity $\left(E>10^{-5}\right)$ according to the results of the BLASTX searches against the available databases.

Each sequence was searched against the non-redundant protein database of GenBank to obtain qualitative information about the ESTs. As a result, 696 ESTs (45.4\%) encode putative amino acid sequences with high significant similarities to those registered in the NCBI.

A total of 2571 annotated ESTs were also given a putative functional assignment according to a MIPS (Munich Information center for Protein Sequences) classification system and the expression profile as revealed by EST analysis is summarized in Table 3. This annotation allows the classification of generated ESTs by function (24) with the aim to create a universal vocabulary for consensus annotation (6).

All annotated ESTs were classified into 18 functional categories. Unique transcripts involved in energy were the largest group accounting for 831 (32.32\%) of the annotated ESTs. The following categories included more highly expressed genes a) metabolism 572 ESTs (22.25\%), where similar representation of ESTs from the cell metabolism category was reported for other normalized cDNA libraries (3), b) protein synthesis 369 ESTs $(14.35 \%)$, c) sub-cellular 
Table 3. Summary of the EST analysis from $N$. tabacum cDNA library

\begin{tabular}{|c|c|c|c|c|}
\hline Functional category $^{a}$ & $\begin{array}{l}\text { Number of } \\
\text { TUTs }\end{array}$ & $\begin{array}{l}\text { Number of } \\
\text { ESTs }\end{array}$ & $\begin{array}{c}\text { Redundancy } \\
\text { factor }^{b}\end{array}$ & $\begin{array}{c}\text { Percentage in annotation } \\
\text { ESTs (\%) }\end{array}$ \\
\hline Energy & 196 & 831 & 4.24 & 32.32 \\
\hline Metabolism & 126 & 572 & 4.54 & 22.25 \\
\hline Protein synthesis & 219 & 369 & 1.68 & 14.35 \\
\hline Sub-cellular localization & 137 & 261 & 1.90 & 10.15 \\
\hline Protein fate & 83 & 136 & 1.64 & 5.27 \\
\hline Cellular transport and transport mechanism & 63 & 113 & 1.79 & 4.39 \\
\hline Defense and virulence & 34 & 106 & 3.12 & 4.12 \\
\hline Biogenesis of cellular components & 40 & 85 & 2.12 & 3.31 \\
\hline Transcription & 22 & 25 & 1.14 & 0.97 \\
\hline $\begin{array}{l}\text { Protein with binding function or cofactor } \\
\text { requirement (structural or catalytic) }\end{array}$ & 12 & 24 & 2 & 0.93 \\
\hline Cell cycle and DNA processing & 9 & 10 & 1.11 & 0.39 \\
\hline $\begin{array}{l}\text { Cellular communication/signal transduction } \\
\text { mechanism }\end{array}$ & 5 & 7 & 1.4 & 0.27 \\
\hline Interaction with the cellular environment & 4 & 7 & 1.75 & 0.27 \\
\hline Transport facilitation & 4 & 5 & 1.25 & 0.19 \\
\hline Storage protein & 2 & 2 & 1 & 0.08 \\
\hline Cell type differentiation & 0 & 0 & 0 & 0 \\
\hline Development (systemic) & 0 & 0 & 0 & 0 \\
\hline Unclassified proteins & 14 & 18 & 1.28 & 0.70 \\
\hline Total & 970 & 2571 & 2.65 & 100.00 \\
\hline
\end{tabular}

${ }^{a}$ Categories were assigned according to MIPS Functional Catalogue Database by Gene Ontology annotation.

${ }^{\mathrm{b}}$ Redundancy factor $=$ number of ESTs/TUTs of a given category.

localization 261 ESTs $(10.15 \%)$, d) protein fate 136 ESTs $(5.27 \%)$, e) cellular transport and transport mechanism 113 ESTs (4.39\%), f) defense and virulence 106 ESTs (4.12\%), and $\mathrm{g}$ ) biogenesis of cellular components 85 ESTs (3.31\%) in turn. This result shows that the normalization step that took place in the construction of the cDNA libraries was efficient in diminishing the level of highly abundant transcripts equally represented in the different analyzed tissues.

The percentage in the other classified function groups was less than $1 \%$. The redundancy factor in energy and metabolism were highest (4.24 and 4.54 respectively) compared with other categories and the average level of redundancy factor in all the annotated TUTs was calculated to be 2.65. The percent of redundancy was high because some highly redundant sequences were observed, most of them were housekeeping genes which in this study includes the energy category (example RuBisCO) and metabolism which includes genes encoding proteins involved in photosynthesis. HöFTE et al. (19) found redundancy among the different libraries, with RuBisCO showing the highest level.

\section{Highly expressed genes}

Since multiple ESTs can be derived from a single gene, the 5927 ESTs were assembled into contigs and singletons to estimate the total number of genes giving rise to the ESTs. These ESTs were assembled into 521 contigs and 3079 singletons. A total of 18 highly expressed genes as represented by contigs composed of 20 or more ESTs is listed in Table 4.

The most abundant contig (CLS_1_contig_CL1Contig1) comprising 246 ESTs (4.15\% in ESTs) was found to be highly homologous to the ribulose bisphosphate carboxylase small chain, chloroplast precursor (EC 4.1.1.39) (RuBisCO small subunit) (TSSU3-8) gene of Nicotiana sylvestris. The second most abundant unique transcript (1.3\% in ESTs) was CLS_32_contig_CL4Contig2 encoding the chloroplast precursor of plastocyanin from $\mathrm{Lyco}$ persicon esculentum. There were highly abundant genes homologous to ribulose bisphosphate carboxylase small chain, chloroplast precursor (EC 4.1.1.39) (RuBisCO small subunit) (TSSU3-8) from Nicotiana sylvestris. This included 68 and 56 ESTs (1.15, 0.94\% in ESTs). Homologues of the translationally controlled tumor protein (TCTP) gene, the chlorophyll a-b binding protein 16 gene, chloroplast precursor (LHCII type ICAB-16) (LHCP) gene and photosystem II $10 \mathrm{kDa}$ polypeptide, chloroplast precursor (PII10) gene from Nicotiana tabacum could be found in our library.

\section{Homologous comparison to other organism}

After excluding 2450 non-significant TUTs in sequence similarity, 100 unique sequences (only $1.67 \%$ of total TUTs) were identified from the $N$. tabacum database and the remaining 1050 TUTs showed partial homology to the genes of the other organisms (Table 5).

249 TUTs $(6.92 \%$ of total TUTs) had most significant sequence similarity to Arabidopsis thaliana. The second mostly matched species excluding $N$. tabacum was Lycopersicon esculentum with 80 TUTs $(2.22 \%)$ and only a few significant matches were found against Homo sapiens $(0.72 \%)$, Cyanobacteria $(0.36 \%)$, Eukaryotes $(0.16 \%)$, Ascomycetes $(0.33 \%)$ and other organism $(0.47 \%)$ according to BLASTX analysis with a level of significance of $95 \%$. 
Table 4. The TUTs expressed predominantly as measured by EST redundancy

\begin{tabular}{|c|c|c|c|c|}
\hline Contig & BLASTX annotation ${ }^{a}$ & Organism & Evalue & Number of ESTs \\
\hline CLS_1_contig_CL1Contig1 & $\begin{array}{l}\text { Ribulose bisphosphate carboxylase small chain, } \\
\text { chloroplast precursor (EC 4.1.1.39) (RuBisCO } \\
\text { small subunit) (TSSU3-8) }\end{array}$ & Nicotiana sylvestris & 0 & 246 \\
\hline CLS_32_contig_CL4Contig2 & Plastocyanin, chloroplast precursor & $\begin{array}{l}\text { Lycopersicon } \\
\text { esculentum }\end{array}$ & 0 & 77 \\
\hline CLS_33_contig_CL5Contig1 & $\begin{array}{l}\text { Translationally controlled tumor protein homologue } \\
\text { (TCTP) }\end{array}$ & Nicotiana tabacum & 0 & 70 \\
\hline CLS_2_contig_CL1Contig2 & $\begin{array}{l}\text { Ribulose bisphosphate carboxylase small chain, } \\
\text { chloroplast precursor (EC 4.1.1.39) (RuBisCO } \\
\text { small subunit) (TSSU3-8) }\end{array}$ & Nicotiana sylvestris & 0 & 68 \\
\hline CLS_25_contig_CL3Contig1 & Metallothionein-like protein type 2 & Nicotiana glutinosa & $2 E-26$ & 65 \\
\hline CLS_3_contig_CL1Contig3 & $\begin{array}{l}\text { Ribulose bisphosphate carboxylase small chain } \\
\text { S41, chloroplast precursor (EC 4.1.1.39) } \\
\text { (RuBisCO small subunit S41) }\end{array}$ & Nicotiana sylvestris & 0 & 56 \\
\hline CLS_12_contig_CL2Contig8 & $\begin{array}{l}\text { Chlorophyll a-b binding protein 16, chloroplast } \\
\text { precursor (LHCII type I CAB-16) (LHCP) }\end{array}$ & Nicotiana tabacum & 0 & 48 \\
\hline CLS_34_contig_CL6Contig1 & $\begin{array}{l}\text { Photosystem II } 10 \mathrm{kDa} \text { polypeptide, chloroplast } \\
\text { precursor (PII10) }\end{array}$ & Nicotiana tabacum & 0 & 37 \\
\hline CLS_43_contig_CL10Contig1 & Basic endochitinase 2 precursor (EC 3.2.1.14) & Oryza sativa & $1 \mathrm{E}-14$ & 35 \\
\hline CLS_35_contig_CL6Contig2 & $\begin{array}{l}\text { Photosystem II } 10 \mathrm{kDa} \text { polypeptide, chloroplast } \\
\text { precursor (PII10) }\end{array}$ & Nicotiana tabacum & 0 & 30 \\
\hline CLS_27_contig_CL3Contig3 & Metallothionein-like protein type 2 & Nicotiana glutinosa & $1 \mathrm{E}-27$ & 29 \\
\hline CLS_28_contig_CL3Contig4 & Metallothionein-like protein type 2 & Nicotiana glutinosa & $4 \mathrm{E}-11$ & 28 \\
\hline CLS_51_contig_CL14Contig1 & Auxin-repressed $12.5 \mathrm{kDa}$ protein & - & $2 E-26$ & 25 \\
\hline CLS_66_contig_CL18Contig1 & $\begin{array}{l}\text { Oxygen-evolving enhancer protein } 3 \text {, chloroplast } \\
\text { precursor (OEE3) ( } 16 \mathrm{kDa} \text { subunit of oxygen } \\
\text { evolving system of photosystem II) } \\
\text { (OEC } 16 \mathrm{kDa} \text { subunit) }\end{array}$ & Spinacia oleraceae & 0 & 23 \\
\hline CLS_38_contig_CL8Contig1 & $\begin{array}{l}\text { Photosystem II reaction center W protein, } \\
\text { chloroplast precursor (PSII } 6.1 \text { kDa protein) }\end{array}$ & Spinacia oleraceae & $1 \mathrm{E}-26$ & 22 \\
\hline CLS_36_contig_CL7Contig1 & Probable protease inhibitor P322 precursor & Solanum tuberosum & $4 \mathrm{E}-15$ & 21 \\
\hline CLS_42_contig_CL9Contig3 & Ferredoxin I, chloroplast precursor & $\begin{array}{l}\text { Lycopersicon } \\
\text { esculentum }\end{array}$ & 0 & 21 \\
\hline CLS_37_contig_CL7Contig2 & Probable protease inhibitor P322 precursor & Solanum tuberosum & $2 \mathrm{E}-13$ & 20 \\
\hline
\end{tabular}

a BLASTX annotation was assigned by Gene Ontology term according to results of the highest scoring BLASTX hit used to compare our consensus cluster sequences against UniProt database by the corresponding EST number $>20$, otherwise no BLASTX hit was listed.

Table 5. Percentage of $N$. tabacum TUTs with homology to species

\begin{tabular}{lcc}
\hline Organism & Number of TUTs & Percentage (\%) \\
\hline Arabidopsis thaliana & 249 & 6.92 \\
Nicotiana tabacum & 100 & 2.77 \\
Lycopersicon esculentum & 80 & 2.22 \\
Solanum tuberosum & 39 & 1.08 \\
Nicotiana sylvestris & 27 & 0.75 \\
Other plants & 308 & 8.55 \\
Homo sapiens & 26 & 0.72 \\
Cyanobacteria & 13 & 0.36 \\
Other bacteria & 13 & 0.36 \\
Eukaryotes & 6 & 0.16 \\
Ascomycetes & 12 & 0.33 \\
Other organisms & 17 & 0.47 \\
\hline
\end{tabular}

\section{Analysis of cDNA array data and identification of differentially expressed genes}

To identify gene expression among the 5289 clones (http://www.estarray.org/san/xest/index.asp?sp=tbt) the amplified cDNAs were arrayed on nylon filters and were hybridized with ${ }^{32} \mathrm{P}$-labeled mRNA probes from separate RNA isolations of four different tobacco varieties (Hongda, NC82, Yun 201 and YH05).

After comparing the hybridization data 359 high quality ESTs were generated and analyzed using the Cyber-T statistic program (Table 6). This program was used to analyze the data set and to examine gene expression levels, the $t$-test was a filter method where two classes of gene expression datasets were compared. In this study four varieties were compared with each other. The chosen genes tend to be strongly expressed in one class and weakly in the other class. This regularized $t$-test approach is available for online use in the Internet at http:/www.igb.uci.edu. The identified genes were significantly differentially expressed if they had a confidence level of $p<0.01$. The average $R^{2}$ was $0.93-0.95$ between replication among the arrays, so DNA array data, at various time points, provided a preliminary assessment of gene activity. This data served as a basis for subsequent experiments at a relevant time point.

In the array result two EST strongly related with tobacco mosaic virus resistance (TMV) were obtained, one basic form of pathogenesis-related protein 1 precursor (TBT012G08) and ubiquitin (TBT087G01). Both of them were found in the variety Hongda. This variety, in accordance with data from 
Table 6. High quality ESTs analysis from array results

\begin{tabular}{|c|c|c|c|c|}
\hline Varieties & EST $^{\mathrm{a}}$ & Annotation $^{\mathrm{b}}$ & E-value & Taxonomy \\
\hline \multirow[t]{3}{*}{ Hongda-NC82 } & TBT001C07 & Pollen specific protein $\mathrm{C} 13$ precursor & $3.00 \mathrm{E}-18$ & - \\
\hline & TBT046G07 & No annotation & 0 & - \\
\hline & TBT106C01 & Histone H4 & $8.00 \mathrm{E}-36$ & Lolium temulentum \\
\hline \multirow[t]{3}{*}{ Hongda-YH05 } & ТВT011B01 & No annotation & 0 & - \\
\hline & TBT108H08 & ATP synthase $6 \mathrm{kDa}$ subunit, mitochondrial & 0 & Solanum tuberosum \\
\hline & TBT112A12 & Metallothionein-like protein type 2 & $4.00 \mathrm{E}-11$ & - \\
\hline \multirow[t]{3}{*}{ Hongda-YUN201 } & TBT012G08 & $\begin{array}{l}\text { Basic form of pathogenesis-related protein } 1 \\
\text { precursor (PRP 1) }\end{array}$ & 0 & N. tabacum \\
\hline & TBT087G01 & Ubiquitin & $1.00 \mathrm{E}-14$ & Ascomycetes \\
\hline & TBT018C04 & No annotation & 0 & - \\
\hline \multirow[t]{3}{*}{ NC82-YH05 } & TBT036E01 & Ferredoxin I, chloroplast precursor & $6.00 \mathrm{E}-17$ & Lycopersicon esculentum \\
\hline & TBT070D01 & $\begin{array}{l}\text { Chlorophyll a-b binding protein CP29.2, } \\
\text { chloroplast precursor }\end{array}$ & $3.00 \mathrm{E}-25$ & Arabidopsis thaliana \\
\hline & TBT115D05 & No annotation & 0 & - \\
\hline \multirow[t]{4}{*}{ NC82-YUN201 } & TBT012G08 & $\begin{array}{l}\text { Basic form of pathogenesis-related } \\
\text { protein } 1 \text { precursor }\end{array}$ & 0 & N. tabacum \\
\hline & TВT065F12 & No annotation & 0 & - \\
\hline & TBT053F03 & Ubiquitin-like protein SMT3 & $5.00 \mathrm{E}-13$ & O. zativa and $A$. thaliana \\
\hline & TBT087G01 & Ubiquitin & $1.00 \mathrm{E}-14$ & Ascomycetes \\
\hline \multirow[t]{4}{*}{ YH05-YUN201 } & TBT045DO5 & $\begin{array}{l}\text { Photosystem I reaction center subunit II, } \\
\text { chloroplast precursor }\end{array}$ & $2.00 \mathrm{E}-24$ & N. sylvestris \\
\hline & ТВT027G08 & Ferredoxin III, chloroplast precursor & $1.00 \mathrm{E}-28$ & Zea mays \\
\hline & ТВТ033С05 & Ubiquitin-like protein SMT3 & $2-00 E-40$ & O. zativa and $A$. thaliana \\
\hline & TBT055G01 & Glycine-rich RNA-binding protein & $3.00 \mathrm{E}-35$ & - \\
\hline
\end{tabular}

${ }^{\text {a }}$ Access number for cDNA used in this study deposited in our GenBank.

${ }^{\mathrm{b}}$ Annotation of clones obtained by universal primer was subjected to homology search against the NCBI database.

Yunnan province, has been reported as susceptible to TMV infection; for that reason it is possible that those genes have a silent effect.

Some other important genes were classified into two groups, one of them implicated in plant development like those genes related to a photosynthetic process (chlorophyll a-b binding protein, photosystem I, ferredoxin I and III, ATP synthase) and the other group including genes related with plant stress response (ubiquitin, ubiquitin-like protein SMT3, glycine-rich RNA binding protein, histones and methallothionein). With the genes found in this study it could be possible to engineer crops to combat environmental stress and this could enhance agricultural efficiency and offer the promise of sustainable local food production.

The functions of several redundant ESTs from the array result could not be identified from the public databases. Most of these ESTs with unknown function do not have homologous sequences in GenBank and may represent genes unique to tobacco.

The aim of the cDNA array data is to identify a large number of genes associated with major physiological and developmental process in tobacco growth and development to open and improve researches in this crop.

\section{Quantitative real-time PCR analysis to validate array results}

Among the 359 genes on the arrays, several of them were selected for further analysis because of the potential physiological significance of the changes (or lack of changes) that were detected (Figure 1). Total RNA was prepared and subsequently reverse transcribed using
oligo(dT) primers. The cDNAs were then used as templates in the PCRs for each set of primers. All parameters of the reaction, such as template concentration and number of cycles, were determined for each set of primers so that the reaction was within the linear range of the PCR (14). Betaactin was used as a control in this experiment. It has previously been shown that $\beta$-actin is a housekeeping gene and therefore was used to confirm that the cDNAs used for each reaction were of the same quality.

Quantitative RT-PCR of six ESTs, most of them representative of this library, confirms that expression levels do not vary considerably between genes as shown in Figure 1. This was in concordance with the microarray results. Most of the ESTs used in this analysis represent housekeeping genes.

\section{DISCUSSION}

\section{ESTs functional annotation and highly expressed genes}

The comparison of the distributions of the functional categories between the ESTs reveals the cellular roles represented by the highly expressed genes (see Table 3 ). This is most obvious for the energy category which includes genes encoding proteins involved in photosynthesis like RuBisCO (4.15\% of total ESTs) and plastocyanin, chloroplast precursor gene (1.30\% of total ESTs). This category of genes, along with those for protein synthesis are sampled more often by random sequencing of cDNA libraries which reflects their general house-keeping role (26). 


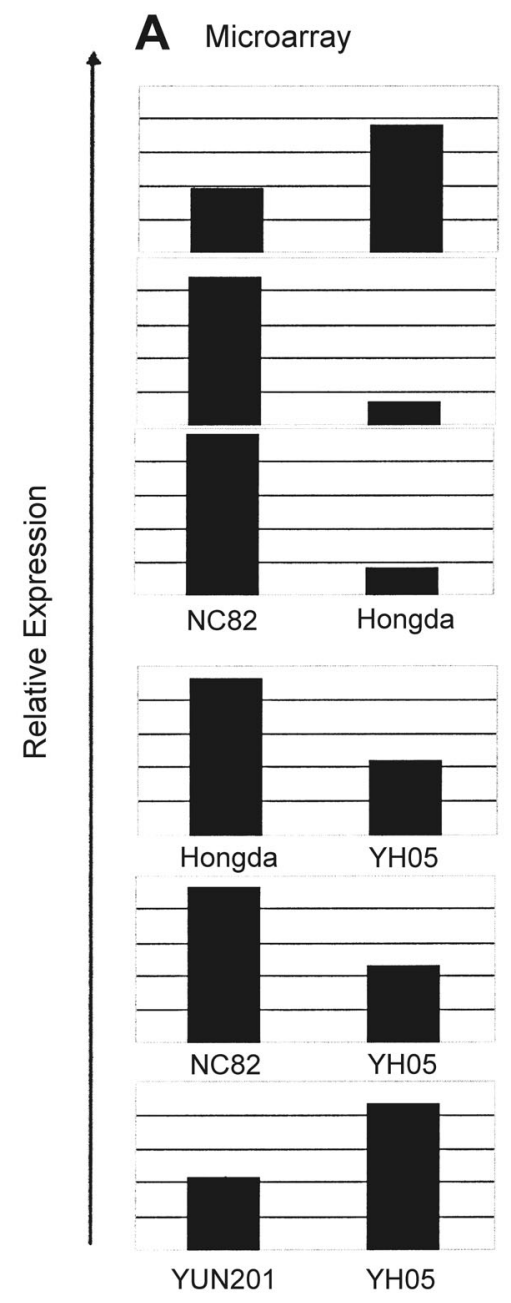

\section{B Q-PCR}

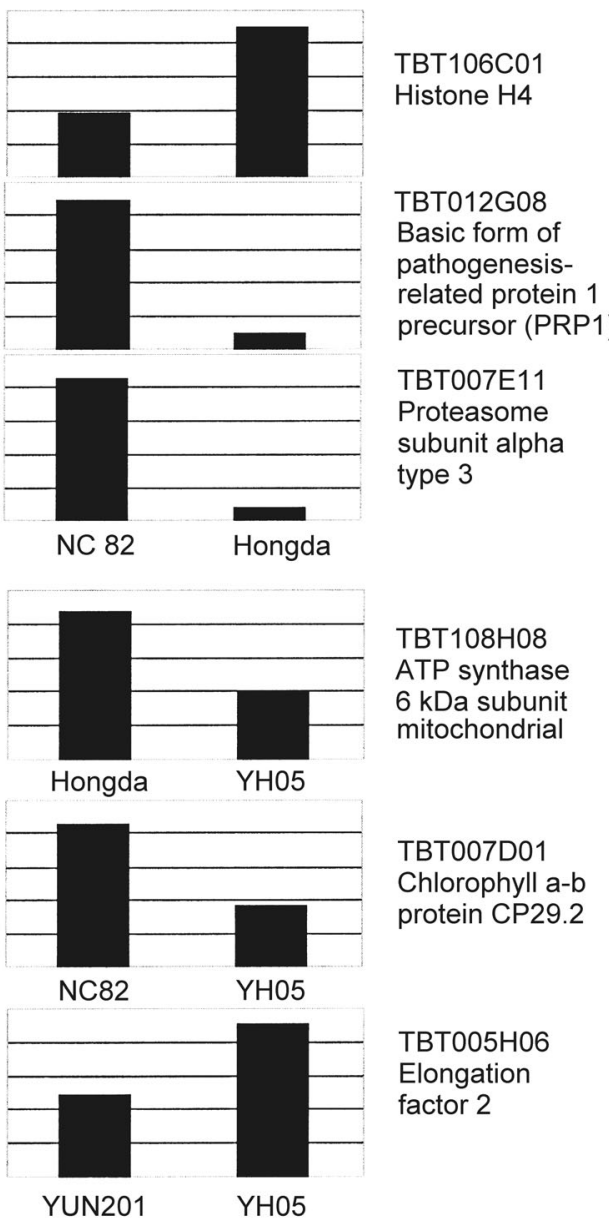

Figure 1. RT-PCR for array validation result: global normalized expression values from microarray experiments (a); relative quantification of genes performed by using real-time detection of PCR amplification (b)

EST programs from photosynthetic organisms normally result in the identification of numerous sequences encoding the small subunit of RuBisCO, the principal enzyme in carbon fixation (19). RuBisCO catalyzes two competing reactions that involve the carboxylation and oxygenation of ribulose-P2, and initiating the primary steps of photosynthetic $\mathrm{C}$ reduction and photorespiration (25). RuBisCO is likely to be the world's must abundant protein comprising approximately $50 \%$ of the soluble protein in green leaves (21).

The electrons oxidized from chlorophyll are the source of initial reduction in the transfer chain. Molecules that specialize in energy transfers in the thylakoids are: nicotine adenine diphosphate (NADP), plastoquinone, two cytochromes, plastocyanin and ferredoxin (13). Plastocyanin is a soluble electron transfer protein found in most photosynthetic organisms. This blue copper protein, which functions as the oxidant of cytochrome $\mathrm{f}$ and the reductant of the P700 reaction center, has been the subject of studies ranging from kinetics (13) to molecular biology (28).

A total of 48 ESTs encoded chlorophyll a-b binding protein that constitutes the antenna system of the photosynthetic apparatus (20). Chlorophyll is the pigment involved in harvesting the light energy for photosynthesis and it is found in the chloroplasts of green plants. This process is the basis of the plant's ability to accumulate carbohydrates (30). Genes involved with chlorophyll a-b binding protein represent $0.81 \%$ of total ESTs.

\section{Differentially expressed genes after array analysis}

Biotic and abiotic stresses, including pathogen attack, drought stress and salt stress, have a serious influence on plant growth, development and crop yield. To adapt to unfavorable environmental conditions, plants develop many responses and many genes are induced. Through this study was promising the identification of functional genes that possibly play roles in stress tolerance, defense reaction and in a general way genes related to plant development.

In the last decade, the cloning of a number of plant genes that confer resistance to various pathogens has brought significant progress in our understanding of host-pathogen interactions. This array analysis shows that there are two genes TBT012G08 and TBT087G01 with relation to TMV in the Hongda variety. TBT012G08 is a basic form of pathogenesis-related protein 1 precursor and TBT087G01 represent ubiquitin.

Pathogenesis-related protein was first discovered in tobacco after TMV infection, hence called PR proteins (31). These 
proteins are induced in several plant species when viruses, viroids, fungi or bacteria infect them. The occurrence of these proteins is not pathogen-specific, but determined by the type of reaction of the host plant. They form a protective barrier against pathogens by collecting at infection sites and act to decrease susceptibility of plants, although they are implicated in plant defense.

Now we can ask: Are the pathogenesis-related proteins involved in tobacco plants resistance to TMV infection? Numerous studies in N. tabacum cvs. Xanthi-NN and Samsun NN have emphasized the relationship between the synthesis of PR1 proteins and the restriction of TMV replication during the hypersensitive response, as well as the correlation between the systemic induction of the PR1 genes and the level of systemic acquired resistance to secondary infections by TMV. However, viral resistance in the absence of PR1 protein synthesis have been reported in some instances. In addition, TMV infection induces PR genes believed to be involved in resistance to bacterial and fungal infections, and the synthesis of the PR1 proteins can be induced by nonviral pathogens (8).

Ubiquitin is a highly conserved 76-amino-acid eukaryotic protein that is covalently attached to proteins as monomers or lysine-linked chains of polyubiquitin (33). Conjugation with ubiquitin can mark a protein down for destruction, particularly if the target protein is polyubiquitinated. However, monoubiquitination is associated with regulation of protein activity or the compartmentalization of proteins in animals and plants $(5,33)$. Speculatively, ubiquitination plays some role in either the in vivo assembly of virions or in their localization in the infected cell. However, the importance, if any, of H-protein remains unknown (34). TMV was the first virus that was found to be ubiquitinated, although subsequently others have been found $(10,17)$.

Now the discussion will be focussed on genes that could participate in tobacco plant development, especially those genes that may play a role in tobacco plant stress response, these genes are ubiquitin, ubiquitin-like protein SMT3 and glycine-rich RNA binding protein.

It is known that ubiquitin participates in various cellular functions by regulating protein degradation in eukaryotes. It is also becoming apparent that ubiquitin functions in the process of environmental stress resistance in eukaryotes. Under environmental stress, the chances of proteins being denatured are greatly increased. Another gene related to ubiquitin was found (TBT053F03) ubiquitin-like protein SMT3, this gene has been reported only in rice and Arabidopsis. Smt 3 is the yeast functional and structural homologue of human Sumo-1 and it belongs to a growing family of ubiquitin-related proteins involved in posttranslational protein modification. Independent studies demonstrate an essential function of Smt3 in the regulation of nucleocytoplasmic transport, and suggest a role in cell-cycle regulation (27). Further studies of this gene in plants could be useful as these posttranslational protein modifications are an important means to regulate the activities and functions of many proteins in cells.

TBT055G01 is a Glycine-rich RNA-binding protein (GRPs). During the past decade, a number of RNA-binding proteins have been found in plants. Some of them were identified as GRPs (16). It has been suggested that some may be involved in stress response, as their mRNA accu- mulation level was modified following exposure to cold, wounding, acute hypersensitive response, abscisic acid treatment, salicylic acid treatment, or water stress. For example, GRP homologues in Arabidopsis thaliana (AtGRP7 and AtGRP8) are regulated by low temperature as well as the circadian clock $(32,7,18)$, and most of rbp genes in Anabaena sp. PCC 7120 are known to be induced by low temperature (11). But the physiological function of glycine-rich proteins remains largely unknown.

Methallothionein may play a role in tobacco metabolism. Transition metal elements such as iron (Fe), cobalt (Co), nickel $(\mathrm{Ni})$, copper $(\mathrm{Cu})$ and zinc $(\mathrm{Zn})$ play a wide variety of roles in biology as enzyme cofactors and must be absorbed from the soil by plants. However, either naturally or as a result of human activity, these metals can be present at potentially toxic concentrations. A number of other metal ions with no known biological function, including cadmium $(\mathrm{Cd})$, lead $(\mathrm{Pb})$ and mercury $(\mathrm{Hg})$, are also potentially highly toxic for plants. There are two basic strategies for decreasing the toxicity of metals: chelation or efflux from the cytosol, either into the apoplast, or by intracellular sequestration. Metallothioneins are defined as low molecular mass cysteine-rich proteins that can bind heavy metals and may play a role in their intracellular sequestration (23). Metallothioneins play a role in detoxification of heavy metals and in homeostasis of intracellular metal ions (9). However, their exact function is still not completely understood.

Through this study some genes related to the photosynthetic process were also found. Photosynthesis is the biochemical process in green plants and algae, which supports most of the life on earth.

After this analysis it is possible to say that the genes TBT012G08 and TBT087G01 have a high relation to TMV and further investigation may be required to demonstrate more clearly if these genes could be used by tobacco plants to defend itself against TMV infection. Two of the ESTs reported here have never been reported in tobacco before, these are ubiquitin-like protein SMT3 and methallothionein and further studies are necessary to establish the function of them in this crop.

\section{CONCLUSION}

The array analysis achieved through this research provides a picture of some genes potentially involved in plant defense and plant resistance against TMV. In this context it is encouraging to note that from 359 high quality ESTs generated two genes TBT012G08 and TBT087G01 are related to TMV. This study, like others, shows that it is fruitful to characterize a number of different cDNA libraries, and thus the coordinated international effort on TMV is providing the community with valuable data for gene identification, protein prediction and DNA array production.

The results exposed here also provide an entry point and a reference to future analysis of gene expression during plant stresses. In addition, these results can suggest possible targets for the enhancement of stress tolerance in crops by genetic engineering. Thus, it may be possible to enhance the tolerance of plants to multiple stresses by regulating the expression of different genes identified by this study. 
Another important group of genes found in this research has a high relation with the photosynthetic process, such processes have a great importance in plant development. It is essential to take into account that two of the genes reported in this study have never been reported in tobacco plants before so further studies are recommended to get a more clear role of these genes in this crop. Additional studies will help to obtain a substantial improvement in $N$. tabacum.

\section{REFERENCES}

1. Adams, M.D., J.M. Kelley, J.D. Gocayne, M. Dubnick, M.H. Polymeropoulos, H.C. Xiao, R. Merril, A. Wu, B. Olde, R.F. Moreno, A.R. Kerlavage, W.R. McCombie, and J.C. Venter: Complementary DNA sequencing: Expressed sequence tags and human genome project; Science 252 (1991) 1651-1656.

2. Adams, M.D., M. Dubnick, A.R. Kerlavage, R. Moreno, J.M. Kelley, T.R. Utterback, J.W. Nagle, C. Fields, and J.C. Venter: Sequence identification of 2375 human brain genes; Nature 355 (1992) 632-634.

3. Ali, S., B. Holloway, and W.C. Taylor: Normalization of cereal endosperm EST libraries for structural and functional genomic analysis; Plant Mol. Biol. Rep. 18 (2002) 123-132.

4. Altschul, S.F., T.L. Madden, A.A. Schaffer, J. Zhang, Z. Zhang, W. Miller, and D.J. Lipman: A new generation of protein database search programs; Nucleic Acids Res. 25 (1997) 3389-3402.

5. Bachmair, A., M. Novatchkova, T. Potushak, and F. Eisenhaber: Ubiquitylation in plants: a post-genic look at post-translational modification; Trends Plant Sci. 6 (2001) 463-470.

6. Camon, E., D. Barrell, C. Brooksbank, M. Magrane, and R. Apweiler: The gene ontology annotation (GOA) project-application of GO in Swiss-Prot, TrEMBL and InterPro; Comp. Funct. Genom. 4 (2003) 71-74.

7. Carpenter, C.D., J.A. Krepes, and A.E. Simon: Genes encoding glycine-rich Arabidopsis thaliana proteins with RNA binding motifs are influenced by cold treatment and an endogenous circadian rhythm; Plant Physiol. 104 (1994) 1015-1025.

8. Carr, J.P. and D.F. Klessing: The pathogenesis-related protein of plants; in: Genetic engineering, principles and methods 11, edited by J. Setlow, Plenum, New York, 1989, pp 65-100.

9. Cobbett, C. and P. Goldsbrough: Phytochelatins and metallothioneins: Roles in heavy metal detoxification and homeostasis; Annual Rev. Plant Biol. 53 (2002) 159-182.

10. Dunigan, D.D., R.G. Dietzgen, J.S. Schoelz, and M. Zaitlin: Tobacco mosaic virus particles contain ubiquitinated coat protein subunits; Virology 165 (1988) 310-312.

11. Ehira, S., T. Hamano, T. Hayashida, K. Kojima, H. Nakamoto, T. Hiyama, M. Ohmori, S. Shivaji, and N. Sato: Conserved temperature-dependent expression of RNA-binding proteins in cyanobacteria with different temperature optima; FEMS Microbiol. Letter 225 (2003) 137-142.
12. Ewing, B., L. Hillier, M.C. Wendl, and P. Green.: Base-calling of automated sequencer traces using Phred. I. accuracy assessment; Genome Res. 8 (1998) 175-185.

13. Farver, O. and I. Pecht: Preferred sites and pathways for electron transfer in blue copper proteins; Prog. Clin. Biol. Res. 274 (1988) 269-283.

14. Freeman, W.M., S.J. Walker, and K.E. Vrana: Quantitative RT-PCR: pitfalls and potential; BioTechniques 26 (1999) 112-122, 124-125.

15. Grimmer, M., M. Maunders, and K. Edwards: Genome analysis using expressed sequences markers; Plant and Animal Genomes VIII Conference, January 9-12, Town \& Country Convention Center, San Diego, CA., 2000.

16. Hanano, S., M. Sugita, and M. Sugiura: Isolation of a novel RNA-binding protein and its association with a large ribonucleoprotein particle present in the nucleoplasm of tobacco cells; Plant Molec. Biol. 31 (1996) 57-68.

17. Hazelwood, D. and M. Zaitlin: Ubiquitinated conjugates are found in preparations of several plant viruses; Virology 177 (1) (1990) 352-356.

18. Heintzen, C., M. Nater, K. Apel, and S. Staiger: AtGRP7, a nuclear RNA-binding protein as a component of a circadian-regulated negative feedback loop in Arabidopsis thaliana; Proc. Natl. Acad. Science USA 94 (1997) 8515-8520.

19. Höfte, H., T. Desprez, J. Amselm, H. Chiapello, M. Caboche, A. Moisan, M.F. Jourion, J.L. Charpenteau, P. Berthomieu, D. Guerrier, J. Giraudat, F. Quigley, F. Thomas, D.-Y. Yu, and R. Mache: An inventory of 1152 expressed sequence tags obtained by partial sequencing of cDNA clones from Arabidopsis thaliana; Plant J. 4 (1993) 1051-1061.

20. Jansson, S.: A guide to the Lhc genes and their relatives in Arabidopsis; Trends Plant Sci. 4 (1999) 236-240.

21. King, S.D.: Tobacco fraction 1 protein: A unique genetic marker; Science 191(1976) 429-434.

22. Klein, S.L., R.L. Strausberg, L. Wagner, J. Pontius, S.W. Clifton, and P. Richardson: Genetic and genomic tools for Xenopus research: The NIH Xenopus initiative; Dev. Dyn. 225 (2002) 384-391.

23. Kohler, A., D. Blaudez, M. Chalot, and F. Martin: Cloning and expression of multiple metallothioneins from hybrid poplar; New Philologist 164 (2004) 83-93.

24. Ouzounis, C.A., R.M.R. Coulson, A.J. Enright, V. Kunin, and J.B. Pereira-Leal: Classification schemes for protein structure and function; Nature Rev. 4 (2003) 509-519.

25. Read, B.A. and F.R. Tabita: A hybrid ribulose bisphosphate carboxylase/oxygenase enzyme exhibiting a substantial increase in substrate specificity factor; Biochemistry 31 (1992) 5553-5560.

26. Sawbridge, T., E. Ong, Ch. Binnion, M. Emmerling, K. Meath, K. Nunan, M. O’Neill, F. O'Toole, J. Simmonds, K. Wearne, A. Winkworth, and G. Spangenberg: Generation and analysis of expressed sequence tags in white clover (Trifolium repens L.); Plant Sci. 165 (2003) 1077-1087.

27. Sheng, W. and X. Liao: Solution structure of a yeast 
ubiquitin-like protein Smt3: The role of structurally less defined sequences in protein-protein recognitions; Protein Sci. 11 (2002) 1482-1491.

28. Smeekens, S., C. Bauerle, J. Hageman, K. Keegstra, and P. Weisbeek: The role of transit in the routing of precursors toward different chloroplast compartments; Cell 46 (1986) 365-375.

29. Soares, M.B., M.F. Bonaldo, P. Jelene, L. Su, L. Lawton, and A. Efstratiadis: Construction and characterization of a normalized cDNA library; Proc. Natl. Acad. Sci. USA 91 (1994) 9228-9232.

30. Streitweiser, A and C. Heathcock.: Introduction to Organic Chemistry, MacMillan, New York, 1981.

31. van Loon, L.C. and A. Van Kammen: Polyacrylamide disc electrophoresis of the soluble leaf proteins from Nicotiana tabacum var. "Samsun" and "Samsun NN" II. Changes in protein constitution after infection with tobacco mosaic virus; Virology 40 (1970) 199-211.

32. van Nocker, S. and R.D. Vierstra: Two cDNA from Arabidopsis thaliana encode putative RNA binding proteins containing glycine-rich domains; Plant Molec. Biol. 21 (1993) 695-699.
33. Weissman, A.M.: Themes and variations on ubiquitylation; Nature Rev. Mol. Cell Biol. 2 (2001) 169-178.

34. Zaitlin, M.: Elucidation of the genome organization of tobacco mosaic virus; Philos. Trans. R. Soc. Lond. B. Biol Sci. 29 (1383) 354, (1999) 587-591.

Corresponding author:

Sandra Pérez Alvarez

Agrarian University of Havana

Havana

Cuba

E-mail: sandra05@isch.edu.cu 